Article

\title{
Sharing Property Sharing Labour: The Co-Production of Value in Platform Economies
}

\author{
Sally Zhu \\ School of Law, University of Glasgow, Glasgow G12 8QQ, UK; sally.zhu@glasgow.ac.uk
}

Received: 7 October 2020; Accepted: 27 October 2020; Published: 30 October 2020

\begin{abstract}
The recent meteoric rise of innovative companies in the sharing economy has divided commentators and regulators alike on the question of their socio-economic impact. Do these economic activities herald an equitable and sustainable alternative to existing practices, or are they simply expanding commercial exploitation into greater areas of life? This dichotomy overlooks how these economic activities constitute new assemblages of labour and property, and shape the flow of value amongst their participants. I propose a conceptual mechanism of 'labour-service', whereby labour and value flow through webs of material objects, as a way of examining how organic collaboration is first structured by the laws of property, and then by the dynamics of nascent platform economies. Tracing labour-service through the sharing economy renders a clearer view of the factors that drive collaboration and exploitation, and hopefully can contribute towards more efficacious regulatory measures and advance academic commentary on this emerging phenomenon.
\end{abstract}

Keywords: property; labour; value; sharing-economy; exploitation; collaborative-consumption

\section{Introduction}

Since Airbnb first launched its accommodation rental business and marked the kick-off for a new generation of innovative enterprises that make the subversion of tired industry models their value proposition, the sharing economy, as these enterprises are collectively referred to, has achieved a meteoric rise in public attention. In part, they have done so by realising the latent value of sharing resources we each possess, whether that be physical assets or personal skills. This has led to a schizophrenic fission in commentators' responses, with some emphasising the new economies' potential heralding of a collaborative economic model (Aloni 2016; Botsman and Rogers 2011), and others claiming they are extensions of the 'worst excesses' of commercial exploitation (Kenney and Zysman 2016). Claims of exploitation are especially acute on the topic of labour (Ravenelle 2017; Morozov 2013), however, many of these arguments are specific to the relationship between providers and platforms in the gig economy (Bieber and Moggia 2020; Das Acevedo 2018), and neglect the peer-to-peer aspect of sharing. Huws (1998) and Terranova (2000) advance a different conception of labour as voluntary participation, however, they both adopt an immaterial approach which I argue cannot fully accommodate the sharing of material resources. Instead of accepting the apparent disjunction between collaboration and exploitation (Martin 2016; Richardson 2015), I propose to examine how they come about as a result of the dynamics between labour and property in the process of sharing access to material resources. The aim is to provide a general theoretical account capable of explaining the paradox of how sharing can be simultaneously exploitative and collaborative.

To this end, I propound a conceptual mechanism whereby labour and property interact to transmit value. I begin by drawing upon Locke (1690) and Marx (1887) labour theories of property and value as foundations for my key conceptual claim that labour is bound to objects, then subsequently provided to others as a service made accessible through the exchange of physical goods. I then set out how the institutions of property law impose structures on this transmission of labour through objects, 
before examining how platform economies alter these property structures to change this flow of labour. To this end, I will focus only on those sharing economy activities that involve peer-to-peer exchange of physical goods without the transference of legal ownership (Botsman and Rogers 2011, p. 99), through the intermediary of a digital platform (Wallenstein and Shelat 2017). ${ }^{1}$ Finally, I explore the arguments for collaborative consumption and exploitation, and show how their uneasy coexistence may be explained by the dynamic between the private property foundations of sharing platforms and opposing impetus driven by the underlying conceptual mechanism. The methodology pursued throughout will be analytical, interrogating theoretical and doctrinal concepts and constructing conclusions based on analyses of their formal interactions. I advance no empirical arguments, although I occasionally cite empirical studies conducted by others in support of my claims.

The new sharing economy activities present different assemblages of labour and property (Stabrowski 2017) which circumvent existing legal boundaries, a symptom of which is the challenge they pose to regulatory definition and oversight. My aim in this paper is to propose a theoretical construction of these new activities by tracing the flows of labour and value through the mesh of material objects, and to demonstrate its feasibility by using it to explain the apparent paradox between collaboration and exploitation. In doing so I hope to deepen the conceptual understanding of what collaboration and exploitation entail in the sharing economy, and to prepare the groundwork for further research into how best to design and structure regulatory regimes to achieve the benefits of collaboration while allaying the effects of exploitation.

\section{Labour, Object, and Service}

In this section, I will present the conceptual foundation for my claim that labour (Marx 1887, p. 30) is bound to objects, then subsequently provided as service (Botsman and Rogers 2011; Lovelock and Gummesson 2004) through material access to those objects by persons, and that this is a function of the fundamental material relationship between persons and things. This will be comprised of two broadly defined steps: How labour is invested and embodied in objects, and how that labour is made accessible to others as a service. I will draw upon the labour theories of property and value, represented by their most prominent advocates Locke and Marx, respectively, as my theoretical underpinnings. ${ }^{2}$ I then focus on the aspect of service and explain how this object-mediated service differs from more familiar notions of service, and can act as an alternative route for transferring labour which does not depend on institutional mediation.

\subsection{Labour Embodied in Objects}

The concept of investing labour into physical objects is a familiar idea in the labour theory of property tradition. The process generally entails an intermingling of labour, broadly defined as some purposive human action, with inert objects, which establishes a normative relationship between the labouring person and the object. Locke was a notable scholar in this tradition, and his concern was to explain how the fruits of nature given in common to mankind may be justifiably appropriated by individuals as private property (Locke 1690, chp.5, sct.27). For this, he developed a prototype theory of property which emphasizes the productivity of labour and its necessity for human prosperity as a whole, focussing on how labour can increase the common stock, and how property rules are conducive

1 This would include Turo (https://turo.com), but not Zipcar (www.zipcar.com), where the platform owns the assets.

2 I am not engaging in an exegesis of Locke and Marx's entire philosophies on property, nor am I proposing a comparison between them. My use of Locke and Marx is predominantly to situate my own arguments in a particular philosophical tradition that sees property as having a pre-political aspect organic to the relationship between persons and the material objects they work upon. As such, I will limit my engagement with Marx to his labour theory of value as propounded in Marx (1887), without commenting on his broader theory of labour and its dialectical relationship with the material conditions, for which, see Cohen (1974). I choose these theorists because they ground their normative claims about property and value explicitly in the material relation between persons and things, as opposed to immaterial factors favoured by other prominent progenitors of property theory, for which, see (Kant and Gregor 1996). 
to such an enterprise (Locke 1690; Mossoff 2012). Locke's is a nuanced and materialist approach to labour and property; his requirement that labour must be productive (Locke 1690, chp.5 sct.30) makes clear it is not sufficient to establish a formal relation between labour and object, but there must be some material connection or change which is brought about by this intermingling of labour and object (Claeys 2014).

\subsubsection{Labour as Material Effect}

It is beyond the scope of this paper to expound on the intricacies of Locke's theory, however, there is one salient aspect I would draw from his argument, which is the fundamentally material nature of the nexus between labour and property. Locke saw the connection between labour and object as a material function of their mutual effects in increasing the stock of value available to society. It is evident from the examples he used that labour is something which produces some perceptible change in the object it mingles with, though that threshold may be as low as gathering acorns or as high as improving land by cultivating it (Locke 1690, chp.5, sct.30-33). This change in the object is a direct consequence of the labour that is invested in it, so it may be fair to say that it represents the measure of labour which is now embodied in that object, and remains in that object as long as those changes endure. The land that is ploughed and sown embodies the labour of ploughing and sowing through its changed characteristics of becoming more fertile and producing greater yields. Although Locke did not state so specifically, I would argue that if land which once was cultivated is left to deteriorate to a point where it becomes no different from uncultivated land, then by his logic, it could be said that labour no longer endures in that property which has reverted to its natural state. ${ }^{3}$ There are two significant conclusions from this: The first is that labour creates a material change in the object regardless how imperceptible it is; the second is that labour is stored in the object, and its effects persist in the material change it wrought upon the object.

\subsubsection{Labour as Material Value}

Another tradition of conceptualising labour-object as material relations lies in the labour theory of value represented by Marx. ${ }^{4}$ This begins from the foundational idea that humans command their labour, which is invested in the object and grounds a normative relationship between object and labourer; in this case, labour is the source of the object's (use) value. Living labour is actualized as concrete labour expended on objects, which in capitalist production then becomes abstract labour through the act of commodity exchange (Marx 1887, pp. 28-42). I wish to draw attention to the way labour is conceptualized first as living labour, which must be realized through the actualisation of labour in a physical object. Once that labour is expended, it becomes an integral part of the object and no longer separable from it as living labour power. If you spend an afternoon building a bench, that part of your potential labour power is exhausted and no longer available to spend elsewhere, and the only way to benefit from it is through the use of the bench (Marx 1887, pp. 126-41). This reinforces my argument that labour is stored within the object, since the two become an inseparable entity. It also raises a further significant point, that labour stored in objects is beyond the control of the provider of labour, for unlike living labour, which may be actualized according to the will of the labourer, dead labour can only be accessed via the object it is embodied in.

3 Locke's foremost concern was the justification of private property, labour was an important means to establish that justification. However his statements on the perils of waste do suggest that if a landowner allowed his lands to go uncultivated, it would presumably be in the natural rights of others to take that land for cultivation, regardless of the property relationship previously established. (Locke 1690, p. 116; Claeys 2014). Reading Locke in this way suggests that property is an ongoing process of continually labouring and justifying the privileged appropriation of property.

4 The similarities and differences between Locke's and Marx's labour theories of value is a much discussed issue, although it is beyond the scope of this paper to comment (Mossoff 2012; Cohen 1995). 


\subsection{Object as Service}

Having established that labour is capable of being embodied in objects in the form of a material change in the properties or value of objects, the foundation is set for examining how that labour subsequently accrues to others as service. In other words, how does the labour of one person becomes accessible by another person as a service in the form of the material object? I will argue that although neither labour theory of property (LTP) nor labour theory of value (LTV) addresses this issue directly, it may be construed from their arguments that this possibility of labour as object-mediated service is fundamentally assumed in both theories.

That value provided by the labour of one person may be accessed by another is nothing novel. Every time a worker gives his labour to the capitalist in return for wages, the fruits of which are appropriated by the latter and sold for profit, the corresponding value of the worker's labour accrues to the capitalist in the form of surplus value (Marx 1887, pp. 131-41). Similarly, whenever a farmer cultivates his land and increases the bushels of harvest it yields, he increases the stock of value by that surplus corresponding to his investment of labour (Locke 1690, chp.5, sct.42-43). This sociality of labour is recognized by both Locke and Marx as necessary to the task of sustaining communities wherein each person must rely to some extent on the labours of others to provide for the necessities of life (Marx and Engels 1964). I argue that a large part of this mutual transference of labour is undertaken through the objects we use to support our daily living, objects which are storage vessels for the past labour of others, reactivated for our usage and benefit. Whenever we interact with an object, we access the labour embodied in that object and derive its benefits as a tangible service. These service points are spread throughout the space we build and share with others, and whenever we use these for our benefit, we are accessing the past labour of others in the form of object as service.

Service: Direct and Indirect

For all that Locke and Marx affirm the necessity for sociality of labour, there is simultaneously an anxiety that the fruits of labour should accrue only to particular persons in the first instance, specifically they who provided the labour. Hence the central concern of LTP to protect a person's labour by taking the object laboured upon out of the common stock and unavailable for others' appropriation (Locke 1690, chp.5, sct.37), and the claim by Marx that workers' labour are exploited when they provide more value in production than they are given in wages (Marx 1887, pp. 127-31). I argue that this concern with allocating the benefits of labour attests to the recognition that service through objects is fundamentally different from service directly provided between persons. This is a logical result of my earlier claim that labour embodied in objects is outside the control of its originator, for it is the physical object that is the point of access to labour and hence the source of service.

There are two ways a person's labour may be transferred to others as service; the first is to provide the labour directly, the second is indirectly through the objects they both access. Direct provision of labour takes the familiar forms of agreement or promising, such as someone promising another to build a bench for him. In this case the provider of labour has control whether to expend his labour and some measure of influence over the terms under which his service is alienated. Indirect provision of labour takes the form of that object-mediated service I have propounded, whereby one person's labour is first stored in a physical object then later accessed by another through the use of that object; someone builds a bench for whatever reason, and his labour persists in that object and provides a service to the person who uses the bench. In this case, the provider of labour has lost control over who may access his labour and under what terms, as his past labour is accessible by anyone with access to the object.

This element of control over the provision of labour differentiates direct and indirect service in two fundamental aspects; one is how the flow of labour and value is structured, the other is the means through which labour is accessed. I will address the means of the access aspect in the next section. Addressing the flow of the labour and value aspects, I argue that direct service is characterized by a one-to-one value structure, whereas object-mediated service is characterized by a many-to-many structure; these are not perfect categories, and the primary difference lies in the presence or absence 
of an enduring physical object which embodies the value of labour. If I agree with you for a haircut, the value of your labour will be intentionally directed by you towards my benefit, after which it will be exhausted and I will sport a new hairstyle. There is little opportunity for others to benefit from that same labour, so the value structure is one-to-one. In contrast, if I agree with you to build a bench, the value of your labour is similarly directed towards fulfilling my request, however, after which it will be stored in the bench and available as service for not only myself, but others who use it. The benefit derives from the object as a repository of labour separate from its original provider, so offers an alternative route to that person's labour, independent of their volition. This route is open to anyone with access to the object embodying labour, hence many people may benefit from the same labour by unilaterally accessing the object, without the necessity of involving the agency of the labourer.

\subsection{Material and Legal Access}

I now move on to address the second aspect which differentiates direct from indirect service, namely the means of access to both. Labour as object service (henceforth labour-service) offers access to labour directly through material interaction with objects, without institutional intermediation. This means that a person is simultaneously able to unilaterally provide their labour for the benefit of many others through the objects she works upon, and to unilaterally benefit from others' labour through the objects they work upon. Such material access is not dependent on institutions such as property or contract, in other words, a person does not need to have a certain legal relationship with the object, such as owning it, or the labour provider, such as employing them, to access labour embodied in the object. The transfer occurs as a necessary and unavoidable function of the material interactions we have with the objects that we share or come into common contact with. Whenever we interact with objects, we vest some value which is potentially accessible by someone, whether that be ourselves or others. ${ }^{5}$ That is not to say labour-service is capable of realising the same value as legal access; labour which enhances the exchange value of an object is arguably not realisable through use alone, but requires the added legal mechanisms of sale and entitlement to proceeds. Nevertheless, the availability of an alternative mechanism for labour transfer which operates primarily through material processes poses an issue of how to control the flow of labour value.

Locke and Marx both addressed this issue, albeit with different conclusions. For Locke, labour invested in objects requires protection in the form of property rights which delimit how third parties may interact with objects that have been appropriated through labour. LTP contrives to extend the labourer's agency over his alienated labour by placing the physical embodiment of labour under his control, by placing legal barriers around access to the physical object, restricting third parties and subjecting their access to the consent of the owner, hence curbing the ability to unilaterally access others' labour through objects. In contrast, Marx views the extraction of living labour in the service of capital (dead labour), which is enabled by the accumulation of means of production through private property to be the basis of exploitation (Marx 1887, pp. 162-74). Legal barriers around objects protect the past labour they embody, but at the expense of living labour whose value is expropriated through capitalist means of exchange. This points to a crucial difference in what Locke and Marx perceive as justifiable constraints on the flows of labour, namely that for Locke, money as the stored value of past labour is commensurable in exchange for present labour (Locke 1690, chp. 5, sct.47-48), whereas for Marx, money as a fetishized commodity cannot be, which becomes significant in the later discussion on property. ${ }^{6}$ What is clear from both accounts is the importance of such barriers around the object itself as a primary means of controlling access to labour value, which attests to the potency of the labour embodied in the object.

5 For the most part, this value will be negligible in its effects; one person using a desktop will not noticeably alter the experience of the next user. This value may also be positive or negative; if the first user deletes a software programme from the desktop, that will have a negative value for the next user who must reinstall it.

6 See Section 5.2 below. 
Sociality of Labour or Sociality of Value

This web of object-mediated transfers of labour presents a way of conceptualising the sociality of labour, whereby participants cooperate by drawing on the benefits of each other's labour through the material objects they share access to. It may be argued that this account neglects to consider the socially constructed aspect of value in general, that by focussing on labour as value it fails to see how value is an effect of the broader social process of valuing, labour included. Indeed, some commentators on digital economy and culture and proponents of immaterialism are of the opinion that the labour theory of value is ill-suited to analysing activities such as the sharing economy or digital networks owing to the increased incidence of affective and mental labour in creating value on these networks (Arvidsson and Colleoni 2012). Alternatively, that value is produced by the labours of communication and engagement rather than physical toil, apprehended by new techniques of extraction (Terranova 2004). While I do not disagree with such accounts, my intention is to reassert the material underpinnings of the sharing economy, which is part of the digital economy, against the prevailing narrative that increasingly construes the digital economy as a weightless phenomenon (Rifkin 2001). Far from seamlessly commanding physical resources into a model of access on-demand and transcending the bounds of space, digital platforms remain reliant on the material and locally situated efforts of their participants to re-produce the market. Specifically, to co-produce value through the mutual transference of labour through property. I aim to demonstrate this by reconstituting the labour theory of value and using that to construct the mechanism of cooperation, thereby reconstituting the material into our digitally intermediated relations.

\section{Modes of Property}

Throughout the above, I have alluded to legal barriers whose purpose is to impede the free flow of labour-service by limiting opportunities to access physical objects, either to protect the labour embodied in the object, or to enable the extraction of labour attached to the object. In the Global North, these barriers generally take the form of property law, specifically the notion of ownership as the standard form of relations between persons and objects. In this section, I will explore how labour-service operates in the context of institutions of property and what this implies for flows of labour and value, especially when the default appears to be ownership and the creation of inaccessible pools of value in the form of fenced off private property. I reference only the laws of England and Wales, but many of the underlying concepts are equally applicable to other common law jurisdictions.

\subsection{Ownership}

If labour-service is envisioned as a flow mediated through objects, then the property mode of ownership may be likened to a dam which collects that flow by restricting access to physical objects through institutional means. The legal owner exerts exclusive control over the disposition (Claeys 2011) of his property, which in many instances means excluding access (Merrill 1998) by others to his property and the labour-service embodied in them. The defining characteristic of ownership is that the owner must bear the entirety of risk and costs associated with ownership, which can include items such as purchase price, registration, tax, and responsibility for eventualities such as malfunction, damage, and replacement (Saccani et al. 2017). These burdens (Moeller and Wittkowski 2010) represent his continued investment of labour in the property and are often inalienable (Stern 2017). In return, the owner is assured the right to exclusive use of the property and to retain any profit derived from or increase in value of the property.

This exclusivity of control and access over the disposition of property means whatever labour the owner invests in the property is highly likely to be preserved for his exclusive benefit. Labour-service in this case is 'self-service' in the sense that owners retain the benefit of their own or another's labour, embodied in their property as utility or market value and fully accessible by them exclusively. This in turn precludes the possibility of others accessing the owner's labour-service by limiting their material 
access to the objects which embody his labour, but also precludes the owner from enjoying the potential benefits of others' labour by not allowing them the opportunity to access and possibly invest value into his property.

Hence, it may be seen that under the mode of ownership, the flow of labour-service is largely contained, and the ability to access others' labour unilaterally without resorting to legal means is largely foreclosed. Insofar as labour-service facilitates co-production of value, ownership offers little organic possibility, as value is preserved for owners to realize, and any cooperation in increasing the value of a property will ultimately accrue to owners exclusively.

\subsection{Possession}

Whilst the mode of ownership as exclusion arguably remains the theoretical paradigm, in practice its legal barriers are far from watertight, and opportunities for the flow of labour-service arise whenever there is a separation of legal ownership from physical possession (Sheehan 2017, pp. 1-32). Such a situation may arise under diverse legal headings, from bailment on terms to theft, the vital point is that ownership remains with the non-possessor, such that any value vested in the object will ultimately accrue to the owner and not the possessor.

The defining characteristic of the possessory mode of property is the transference of labour-service from one party to another, by enabling non-owners to access a part of the owner's labour through the means of using their property. Specifically, those burdens of purchase, maintenance, and replacement which represent the past and continuing labour of the owner to invest in the property through the expenditure of time and money. Conversely, the possessor's ability to access the owner's labour is restricted to what he can derive through material use and enjoyment of the object. He is not free to sell or otherwise commercially exploit the object, so cannot access its market value despite potentially contributing to its enhancement, such as a tenant refurbishing a flat. However, as long as the possessor has physical access to the object, he enjoys not only the self-service of his own labour invested in it, but the service of the owner's labour. In this sense, the possessory mode enables 'other-service' by using the material object as the nexus for mutual transfer of labour.

The possessory mode enables flows of labour-service across ownership barriers, and the possessor will gain access to that part of the owner's labour-service irrespective of the law's prescriptions, as labour-service flows through the very act of material access to the object. Possession represents instances of other-service and co-production operating through private property, but nonetheless circumventing full institutional control insofar as parties may stipulate terms of access, but cannot prevent their labour-service from flowing through the object once access has been allowed.

\subsection{Open-Access}

The final mode of object relations to discuss is that of open-access to a common pool resource (Ostrom 1990), often referred to as commons (Euler 2018), which straddles the boundaries of private and public property. Some commons defy institutional means of containing their benefits or access, and some are deliberately opened to common access (Mankiw 2018, pp. 220-34). I will focus on common resources, which are material and deductible and access is open to a particular group of people (Ostrom 2003).

Open-access, like possession, is also characterized by the element of other-service that does not pertain with ownership, but swaps the serial access model whereby labour invested by one person is only available to subsequent users, for a distributed model whereby service is both provided and accessed from multiple points contemporaneously. This is a direct consequence of the openness of access by multiple users and their relative inability to monitor or exclude each other. The vulnerability of open-access resources to over-exploitation (Hardin 1968; Ostrom 1990) is one that applies equally to labour-service as a valuable resource, which suffers from the same dilemma of free-riding behaviour that leads to a reluctance to invest labour unilaterally for fear of being exploited (Guyader 2018). 
Conceptualising commons as a mesh of labour-service transferred through physical objects clearly delineates the flows of labour and value and emphasizes the function of material access in modulating such flows. It also reconstructs how mutual labour-service can occur with minimum coordination between participants, which nevertheless involves the co-production of value for the benefit of others. These deductible resources are fully susceptible to private ownership, but insofar as access is open to multiple parties, the flow of labour-service cannot be stemmed through institutional means, and as such open-access represents another mode of circumventing ownership barriers.

\subsection{Inaccessible Value}

It appears this element of other-service is a potential source of value that is largely foreclosed by the paradigm of ownership, but finds some opportunity for realisation through possession and open-access. Property law in guarding against the risks of moral hazard has drawn the default line decidedly in favour of private spheres of costs and benefits. Property theorists have in turn argued that centralising all the rights of disposition under the control of one individual is conducive, indeed necessary, to the efficient governance and use of resources (Nozick 1974). A common argument proceeds from an assumption that rational agents have no incentive to invest in property without the guarantee that the rewards of his efforts can be safeguarded for his benefit alone. This structure of incentive and reward, it is argued, leads to the most economically efficient outcome when evaluated on the marginal product of resource use, and is largely replicated in property law (Claeys 2011; Merrill 1998).

This brings about a situation wherein much of the gratuitous labour we undertake and its value are invested in our private possessions for our own benefit, or self-service, which is both incentivized and protected from outside exploitation through the rights guaranteed to ownership. This represents a not inconsiderable pool of value that is fenced off through the operation of the law, restricting access to private property and ensuring that value accrues to the owner. At the same time, these property rules not only fence off resources, but also extract the labour-service of others by monopolising their value (Marx 1887). There are exceptions when ownership and possession are separated, or when access to resources cannot or is deliberately not restricted, however, the legal default which is ownership is not conducive to the mutual exchange of labour-service by sharing resources. ${ }^{7}$

Critics have argued that this leads to a situation of inefficiency due to excessive and unnecessary utility loss in the form of over-consumption and idle resources (Sundararajan 2016). In addition, the possibility of realising the considerable value latent in networks and coordinated co-production is stifled by the institutional barriers to cooperation (Benkler 2006). Protecting owners from exploitation has resulted in the exclusion of those unable to attain ownership status from the use and enjoyment of value which lies unused, and yet to establish open-access to objects which are material and deductible encounters those familiar hazards of over-exploitation. This dilemma between private and common property models is well-rehearsed and, as Ostrom (1990) has demonstrated in her study of successful commons, also somewhat contrived. The sharing economy presents a different solution to this dilemma which seemingly offers the best of both worlds: The problem of exploitation by exclusion is ameliorated by widening material access to resources, while the problem of free-riding behaviour is avoided by keeping those resources in private ownership. By leveraging private property incentives while opening access for freer flow of labour, the sharing economy gains efficiencies without sacrificing the model of exchange which makes market coordinated activities successful. However, as I will demonstrate in

7 This is not to say that formal legal rules are fully determinative of property practices, as informal practices can and do circumvent institutional norms and in doing so facilitate the free flow of labour-service in spite of legal barriers. Examples of practical significance are neighbourhood associations in various communities, such as Japanese chonaikai and shotenkai, which coordinate common problems such as cleaning shared spaces and decorating shop fronts, and in doing so curb the absolute exercise of owners' legal property rights; (Sorenson 2009). But what is striking about these divergent practices is the level coordination and social cohesion required to make them work; they are more labour intensive because they diverge from the normalised property practices instituted by law and reinforced by State governance. For an argument of the ambiguity of law in constituting property practices, see Morgan and Kuch (2020). 
Section 5, sharing involves exploitative and collaborative aspects which are distinctive to it, and which are not merely the fault of platform practices but stem from the interaction between private property and labour-service at its foundation.

\section{Platform Economies}

Against this background of entrenched private property practices, the sharing economy has managed to thrive on business models which apparently defy the predominant modes of property (Wallenstein and Shelat 2017). Where property law endeavours to obstruct the flow of labour-service by fencing off access to property, platform economies aim to facilitate greater access to property and realize the value embodied in them.

Commentators have espoused the benefits of these new platform economies and their potential for instituting new forms of production and consumption, one that eschews the drawbacks that have plagued neoliberal economies (Belk 2014). In its place will be a new model based on pooling resources and remedying under-utilisation (Aloni 2016), achieving greater sustainability (Geissinger et al. 2019), cooperation, and economic opportunity (Sundararajan 2016). To some extent, these new forms consist in realising the latent value of labour-service and its possibilities for co-production, however, I would not perceive them as subverting the modes of private property. Instead, platforms employ technology to facilitate greater ease and frequency of access through property law and contract. Nevertheless, a result of this is to increase the opportunities for labour-service to operate and materialize its effects, which accrue to users of platforms as tangible benefits.

\subsection{Platform Dynamics}

If property redirects the flow of object-mediated labour, platform economies redirect the flow of property objects, primarily by enabling easier and more frequent access to the pools of value fenced off by private property. They do so by appealing to profit interests and removing the barriers to small scale transactions. There is abundant literature on the economic dynamics of platforms (Evans 2003; Langley and Leyshon 2017). I will briefly mention two aspects which are pertinent to my argument; transaction costs and coordination, which are primarily logistical problems solved by information and communication technology.

Transaction costs are those necessary to making the trade happen, and can include search and information, bargaining, and enforcement. Platforms such as Airbnb solve these barriers by aggregating market information onto one platform, setting the standard terms for use of and transacting on their platform, and enforcing performance through its own monitoring and remedial mechanisms (www.airbnb.com, sct.7-8, sct.15). They also reduce the barriers to communication and trust to facilitate direct contact between users (Teubner et al. 2017) through the use of indigenous messaging tools and payment applications, and governance structures such as ratings and reviews, forums, and reporting systems. The result is to make micro-transactions between individuals economically feasible.

Co-ordination involves matching supply and demand to remedy under-utilisation of assets, by matching owners of unused assets with potential users. Platforms such as Turo solve these coordination problems by providing real time location mapping and channels of communication between transacting parties, which allow car owners and riders to easily locate and contact each other. Participants can identify themselves as willing to transact on an ad-hoc basis by signalling through the platform, allowing flexibility and more efficient use of assets over their lifetime.

\subsection{The Role of Property Institutions}

I innumerate these platform dynamics to draw attention to how they redirect the flow of labour-service through private property, by inducing owners to open access in return for benefit. Recall how under the mode of ownership the owner must bear all the burdens of owning property as the trade-off for retaining all its benefits, thereby foreclosing the possibility of benefiting from someone else's labour. The owner's needs in this case relate to his burdens of ownership; financial outlay, 
risk of obsolescence, cost of maintenance, and so on. By providing his assets on a sharing platform, the owner can recoup some of his costs and monetize some of the capital tied up in the good which might otherwise not be realisable. For the duration of the rental, the owner is also spared the costs of storing, cleaning, and maintaining the good, which temporarily passes to the user as the person with immediate possession of it. Whilst the owner retains much of the risk, simply by delivering physical possession to another for compensation, he can alleviate some of his burdens of ownership in the form of monetary benefit and reallocation of responsibility (Bridge 2015, pp. 94-102). Conversely, those burdens which remain with the owner represent his continuing labour in the object, which accrue to the user as service in the place of foregone demands on his own labour. The user has saved himself these necessary burdens that inevitably come with owning the good whilst effectively accessing the benefits of using the good (Bardhi and Eckhardt 2012; Belk 2014).

The above makes apparent how the needs and demands of owners and users mutually align, and so may be offset against each other for mutual benefit. It also shows how this structure of mutual benefit is only possible under the existing rules of ownership, since it is predicated upon one party bearing those initial burdens (Kochan 2017). Platform companies are sensitive to their users' mutual needs, but also the misalignments in their incentives as parties with different legal relations to the property, hence their solution of providing each party with tools to moderate the other's behaviour. For example, allowing Airbnb hosts to demand deposits assuages their fear that their guest might damage their house and leave them with no financial remedy. These measures are designed not just to overcome the transaction cost barriers to trade, but also the concerns of owners as the ultimate risk bearer for the continued welfare of their property.

Essentially platform economies have constructed on top of existing property structures a system of mechanisms and incentives which aim to realize the value latent in private property. They function primarily to create more opportunities for owners to open access to their property within existing institutional constraints, simultaneously enabling the realisation of value through exchange, whilst maintaining control of the flow of value by setting the terms of access. Platform economies do not subvert the predominant modes of property or herald a new mode of access-consumption, rather they attempt to increase value flow, but strictly within the confines of property, in order to direct that value towards property owners (Schor 2017). However, by increasing the incidence of separating ownership from usership, platforms have also increased the incidence of other-service, and by extension, the potential for greater co-production.

\subsection{Dual Aspects of Platform Economies}

This dynamic of opening the pools of value in private property to access through labour-service, but doing so within the constraints of property law, can explain the schizophrenic characteristic of platform economies as being simultaneously equitable and exploitative. Flows of labour and value potentially accrue to all participants to shared resources, but they do not flow freely, and instead are channelled through the existing structures of property which operate to direct value to the owners of property. On one hand, platform economies are circumventing the legal boundaries of property by routing labour provision through facilitating greater sharing of physical objects. On the other hand, their appeals to participants to monetize their possessions, time, and skills evidences their aim to further accumulate value to capital, which exacerbates inequalities and exploits participants' free labour. I will explore in more detail these opposing arguments and argue that while the institutions of property do enable unequal distribution of value from sharing, they cannot prevent participants from accessing the value of labour-service. 


\section{Collaboration/Exploitation Paradox}

\subsection{Collaborative Consumption}

The above discussion indicated that labour-service could serve as an alternative non-institutional route for allowing persons in a community to access each other's labour through the objects they share access to, thereby constructing a mesh of mutual service in sharing the burdens of ownership and consumption. Proponents of collaborative consumption (CC) rightly capture the collaborative effect of sharing of the means and burdens of production and consumption. Whilst I agree broadly with the CC claim that benefits of lower costs of ownership and consumption accrue to providers and consumers respectively, I differ in how I perceive these effects to come about and what they implicate for collaboration.

Commentators argue that by aggregating the resources of individuals into a common pool, they can generate more value for the benefit of all (Benkler 2004). In contrast, I see the process as two-tiered, whereby the actual benefits of offsetting the burdens of ownership and lowering the cost of access occurs at the individual level, while the benefits of having an available market occurs at the collective level. What I mean is that there are certainly benefits that accrue to providers as a class when they come to the platform (Evans and Schmalensee 2016), which include a ready market of potential buyers and an increased feasibility of ad-hoc renting for offsetting ownership costs. Similarly, consumers benefit from a wider selection of goods to access on-demand, which lowers the risk of scarcity (Lamberton and Rose 2012). My goal in making this distinction is twofold. One is to emphasize that simply pooling privately owned resources will not result in actual benefits accruing to all, but only to those who manage to make transactions and benefit from labour-service by gaining material access to the object (Schor and Attwood-Charles 2017). The other is to separate the labours that are being provided in participating on the market, and those that are provided by engaging in a particular transaction, with the additional implication that the value of their service accrue differently and hence are susceptible to different methods of appropriation.

\subsection{Collaboration Is Not Commoning}

Where I perceive the collaboration argument to be problematic, especially in the context of large scale commercial platforms, is the notion that CC approximates a commons wherein benefits accrue across the community. The argument proceeds that pooling spare resources enables more efficient use and lower barriers to access, potentially approximating an open-access model of multiple points of contribution and access. Fostering a greater sense of community leads to more peer-to-peer collaboration and greater willingness to provide resources for the benefit of the commons, which leads to those benefits accruing to all participants (Hendrickson et al. 2017).

Whilst I would not question the positive outcomes of collaboration, I would hesitate to characterize it as a commons, because that implies all users may access the resource (Ostrom 2003, pp. 248-52). One reason is most CC models are based upon private property, and I would argue that if collaboration is dependent on owners contributing to the common pool, it would be difficult to separate the incentives of private property from the incentives to participate in CC. Currently, participants in CC either already own goods for their own consumption, and in order to obtain further consumption goods the owners use their possessions or money to access a CC community instead of purchasing outright on the market, either through peer-to-peer renting, recycling, trading, or lending. This situation is similar to a decentralized marketplace where participants trade on informal credit and are monitored by reputation and social norms (Ghosh and Ray 2016). Thus, ironically, what makes CC so efficient might be the same forces that drive the private property and free market regimes CC professes to replace.

Another reason CC is more akin to a marketplace than a commons is the terms of access, which although prima facie applies equally, in actuality is differentiated based on ownership of capital (Frenken and Schor 2017). This applies to both tiers of collaborative benefits; participation on the platform requires a certain level of capital either in the form of money or asset to be traded, 
and actualising a transaction requires the coinciding of a participant's wants and the wherewithal to obtain them. This is especially apparent in sharing real estate, where the market gradually stratifies along the relative market values of its offerings; participating on Airbnb in London requires a much higher capital stock than in Bristol. This replicates the inequality of access to goods CC claims to reduce, as the threshold for realising benefits from the collaborative economy continues to stratify along the conditions of capital ownership (Aloni 2016). Even in a situation of free access, sharing economies exhibit patterns of distinction and discrimination which undermine its approximation to a commons. Social capital designates who shares with whom, and empirical studies have shown that trade partners tend to favour those who share their socio-cultural background (Schor et al. 2016). So, despite the common pool being ostensibly open for all to access, actually securing a benefit by securing a trade depends on your level of money and social capital. The institution of property is foundational to platform economies and operates to funnel value back to asset owners, which in Lockean theory is not necessarily problematic, given that the value inherent in property is an extension of the owner's previously expended labour, but in Marxian theory it represents the continuing extraction of labour value to capital. The fundamental element of open-access and hence unhindered labour-service, namely the ability to unilaterally access another's labour, remains constrained by the legal control exerted by participants through the assets they own. Within the logic of private-property based sharing this constraint is a feature which facilitates the coordination of access through market mechanisms. In order to unlock the potential for greater co-production and distribution of value, these institutional constraints should be diminished to allow labour-service to flow freely. Fewer constraints would benefit active participants of CC and better approximate an open-access common, such as may be achieved by a system which rewards participation rather than ownership of valuable goods. For example, a platform which operates an internal currency that is earned based on the number of transactions undertaken, and where participants must commit their goods to be shared and surrender the power of choosing their transaction partners. ${ }^{8}$ Such a system would make trades less bilateral and more multilateral, hence more approximate to an open-access structure, and reduce the power participants exercise over their labour-service as an extension of their power over their private property.

\subsection{The Value of Free Labour}

On the other end of the spectrum, critics of sharing economies accuse platform companies of exploiting their users' labour by undermining worker protection regulations (Morozov 2013; Ravenelle 2017), and profiting from harvesting and selling data they provide for free (Terranova 2000). Insofar as data and engagement are modern proxies for value, the argument that those whose labour has generated the value should control and benefit (De Hert et al. 2018) from it presents a similar argument to LTP and LTV. The overall critique is that commercial platforms are exploiting both their users and the public by unduly profiting from their activities. I want to examine these claims of exploitation and argue that it proceeds as a specific function of the mechanism of labour-service.

Most commercial platforms' direct revenue comes from taking commissions on transactions or selling membership fees and/or advertisement in lieu of fees. However, they also derive value indirectly from having a large and active user base, and often that is their very value proposition for raising venture capital. One benefit is the network effect, which comes at no cost to the platform since the participants provide both the goods and the labour (Traum 2016). Another benefit derives from greater activity on the platform, achieved mostly through encouraging participants to be active and engaging, by using rewards such as status differentials (Das Acevedo 2018) which entitle their holders to priority listing and platform endorsement. In terms of the two tiers of collaborative benefits, the commission derives from the level of actual transactions which see participants take the lion's share of the benefits,

8 Timebanking is one example of such a system, where all tasks earn the same amount of time-currency regardless of their market value. https:/www.timebanking.org/what-is-timebanking/what-is-timebanking/. 
while engagement derives from the collective level of greater participant contribution to the pool of resources hosted on a platform. Hence platforms derive profit from both tiers of collaboration, and importantly these sources of value are generated by the labour of their users, for which they are not compensated.

\subsubsection{Exploitation as Offloading Labour}

The value platforms derive from their users correlate to the labour they exploit from the providers of that value, specifically the labours bearing the burdens of ownership and engaging in transactions, which users necessarily undertake in their continued platform participation. Critics have pointed to the high incidence of do-it-yourself (Huws 1998) that users undertake, which they characterize as free labour exploited by the platforms in the form of lower prices and saved costs (Terranova 2000). At the point of coming to the market, but before any trade takes place, the platform already reaps the benefits listed above at little cost, by offloading the necessary labour involved to the users. Users advertise their supplies and demands, communicate directly with each other, and arrange trade logistics and after-service, essentially all the actions a conventional supplier of goods will do on the market, hence saving the platform these transaction costs. In addition, the users also continue to bear the burdens of ownership for the duration of listing their property, hence saving the platform the costs associated with owning stock. These are all examples of labour which is undertaken by the user, aided by platforms' algorithms and ICT (Werbach 2017), and encouraged by their marketing messages to become micro-entrepreneurs (Dubal 2017; Stabrowski 2017). These are of considerable value to platforms, as they offload the labour of provision to their users without compensating them, which may arguably be characterized as exploitation of their labour. This also explains why some commentators advocate legally walling off this value as the 'property' of its creators in order to prevent its exploitation (Custers and Uršič 2016; Malgieri 2016).

Thus, I would argue that there is an element of exploitation of users' labours of co-producing the marketplace value hosted on platforms which they are not compensated for. Specifically, the providers' ownership associated labours enumerated above, plus theirs and the consumers' engagement to make their transaction possible, are all benefits that accrue to platforms by increasing their network effects, commission revenue, and ability to leverage external funding. There is a gap between the benefit and risk at the collective level of collaboration, which platforms exploit by offloading the ownership and transaction burdens onto users while capturing the value of their co-produced market activities. This gap exists precisely because private property remains the foundational structure for these activities, placing the ultimate responsibility for risk on individual users by default. Again, this is a feature of sharing which leverages the efficiencies of market exchange, and which may not be easily erased without also erasing those efficiencies claimed by CC.

\subsubsection{Benefits Accrue to Users}

Where I perceive the criticism of exploitation to be problematic is its lack of acknowledgement of the benefits that accrue to prosumers, as argued by CC, and which would not arise but for this new model of economic activity. That benefits do accrue to the participants instead of being wholly extracted by platform companies may be demonstrated both conceptually and empirically. I have argued that one person's labour may be accessed by another as service through the object, and in the context of peer-to-peer sharing of physical goods this mechanism operates to transfer the provider's labour to the consumer through the latter's material use of the object being exchanged. If I rent my car on Turo, my previously invested labour plus my ongoing labour are transferred to the consumer who accesses my labour by having the use of a functioning car, and in return I receive direct monetary compensation and their labour of looking after and bearing responsibility for the car during their rental period. Importantly, these mutual labour-service accrue to the transaction parties and not to the platform, as actual benefits that are only available to those parties who have material access to the object. Moreover, these benefits would not otherwise be available; such scale of peer-to-peer transfer of 
labour-service has no historical precedent (Frenken and Schor 2017), and statistics indicate that the economic activity generated by sharing platforms are separate added value to existing commercial activities (Wallenstein and Shelat 2017). This value should be not be so easily dismissed, for they indicate the potential for a more organic co-production and distribution of value through labour-service, whose exploitative elements may be ameliorated by allowing labour-service to flow more freely instead of funnelling it through the channels of property law.

\subsection{Synthesis}

I have presented a general theory of labour-service and shown how its interaction with property manifests the paradoxical features of exploitation and collaboration. While other scholars have also proposed that platforms exploit the free labour of users in creating content and being responsible for their transactions (Bieber and Moggia 2020; Huws 1998; Terranova 2000), they differ in their theoretical scope and conclusions. Bieber and Moggia focus mainly on the labour of bearing uncertainty, and their argument is pertinent for those who pursue sharing activities as an income-generating exercise, but not so much for those who engage sporadically or gratuitously. Terranova's idea of labour as voluntary and driven by self-satisfaction has resemblance to my idea of self-service, however her analysis is of intangible and cultural goods whose characteristics of non-deductibility and non-rivalry mean their flows of labour and benefit differ from those of material resources. Her theory follows a long tradition of labour-based arguments against the fencing off of knowledge commons due to their non-rivalrous character, which does not apply to rivalrous goods. My account also shows which parts of the labour of users are exploited by platforms; Huws' assertion that DIY labour is exploited supports my assertion that the labour of market-making is captured by platforms, but she does not address the labour which goes into maintaining and producing resources, which I have asserted accrue to users as labour-service accessible only via material use. Most importantly, my account shows the uneasy synthesis between labour-service and property achieved on sharing platforms. It is not simply that labour-service underpins collaboration while property enables exploitation, on the contrary, the current success enjoyed by peer-to-peer sharing is driven in equal parts by the opportunities for new means of value realisation through collaboration and access to others' labour-service, and the ability to engage in these exchanges as an extension of existing private property powers. The tension is productive, and one which regulatory design should be cognisant of.

\section{Conclusions}

As the sharing economy phenomena becomes more prominent in the economic activities of modern life, it prompts a host of reactions from commentators and regulators who are concerned by platform companies' persistent undermining of regulation and exploitation of their users (Ferreri and Sanyal 2018). In contrast, their proponents worry that over-enthusiastic regulation will stifle innovation and the potential to build a new collaborative economy (Cohen and Sundararajan 2015). I have argued for an alternative understanding of these activities as new assemblages of property, labour, and value, which have as their conceptual foundation the transference of labour through objects. I have shown how the ostensibly paradoxical elements of collaboration and exploitation present in sharing economies may be explained as manifestations of that same underlying conceptual mechanism of labour-service that pertains whenever objects are accessed in common.

Throughout the paper, I have stated that exploitation is related to the private property structures which remain at the foundation of sharing economies, which operate to direct the flow of labour-service along the familiar lines of ownership of capital. In contrast, the model of property relations immanent within sharing activities tends towards common access and freer flow of labour-service value among participants who engage actively and materially with the objects being shared. The potential to construct a more collaborative economy lies in the mechanism of labour-service in facilitating the co-production and distribution of value in an organic manner, by broadening access to resources 
currently barred by property institutions. This paper has demonstrated how the existence of property barriers at the foundation of a set of activities whose material effects tend strongly towards subverting and overcoming those barriers manifest as the schizophrenic characterisation of sharing economies I have remarked on in the beginning. By theoretically delineating the dynamic between prevailing property norms and insurgent collaborative practices, and how it feeds into the transmission of value and exploitation of the same, the field is opened up for fresh beginnings on the question of appropriate regulatory measures. It is beyond the scope of this paper to expand on the topic of regulation, however, by laying out the contours of the problem, it has provided guiding principles for regulation. I have demonstrated how labour-service creates value by enabling co-operators to access each other's labour through shared resources, and how this value is susceptible to exploitation by being fenced off through property institutions. A regulatory design that aims to promote co-production of value should endeavour to facilitate the free-flow of labour-service by reducing institutional constraints and alleviate the effects of exploitation by shifting the burden of risk towards the beneficiaries of labour value.

Funding: This research was funded by Leverhulme Trust grant number ECF-2018-378.

Conflicts of Interest: The author declares no conflict of interest.

\section{References}

Aloni, Erez. 2016. Pluralizing the 'Sharing' Economy. Washington Law Review 91: 1397-459.

Arvidsson, A., and E. Colleoni. 2012. Value in Informational Capitalism and on the Internet. The Information Society 28: 135. [CrossRef]

Bardhi, Fleura, and Giana M. Eckhardt. 2012. Access-Based Consumption: The Case of Car Sharing. Journal of Consumer Research 39: 881-98. [CrossRef]

Belk, Russell. 2014. You are what you can access: Sharing and collaborative consumption online. Journal of Business Research 67: 1595-600. [CrossRef]

Benkler, Yochai. 2004. Sharing Nicely: On Shareable Goods and the Emergence of Sharing as a Modality of Economic Production. The Yale Law Journal 114: 273-358. [CrossRef]

Benkler, Yochai. 2006. The Wealth of Networks: How Social Production Transforms Markets and Freedom. London and New Haven: Yale University Press.

Bieber, Friedemann, and Jakob Moggia. 2020. Risk Shifts in the Gig Economy: The Normative Case for an Insurance Scheme against the Effects of Precarious Work. Journal of Political Philosophy. [CrossRef]

Botsman, Rachel, and Roo Rogers. 2011. What's Mine is Yours: How Collaborative Consumption is Changing the Way We Live. London: Collins.

Bridge, Michael G. 2015. Personal Property Law, 4th ed. Oxford: Oxford University Press.

Claeys, Eric R. 2011. Exclusion and exclusivity in 'Gridlock'. Arizona Law Review 53: 9.

Claeys, Eric R. 2014. Productive Use in Acquisition, Accession, and Labour Theory. In Philosophical Foundations of Property Law. Edited by J. E. Penner and H. E. Smith. Oxford: Oxford University Press.

Cohen, Gerald A. 1974. Marx's Dialectic of Labor. Philosophy and Public Affairs 3: 235-61.

Cohen, Gerald A. 1995. Self-Ownership, Freedom, and Equality. Cambridge, New York and Paris: Cambridge University Press.

Cohen, Molly, and Arun Sundararajan. 2015. Self-Regulation and Innovation in the Peer-to-Peer Sharing Economy. University of Chicago Law Review Online 82: 116-33.

Custers, Bart, and Helena Uršič. 2016. Big Data and Data Reuse: A Taxonomy of Data Reuse for Balancing Big Data Benefits and Personal Data Protection. International Data Privacy Law 6: 28. [CrossRef]

Das Acevedo, Deepa. 2018. Unbundling Freedom in the Sharing Economy. Southern California Law Review 91: 793-838. [CrossRef]

De Hert, Paul, Vagelis Papakonstantinou, Gianclaudio Malgieri, Laurent Beslay, and Ignacio Sanchez. 2018. The right to data portability in the GDPR: Towards user-centric interoperability of digital services. Computer Law and Security Review 34: 193-203. [CrossRef]

Dubal, Veena B. 2017. Wage Slave or Entrepreneur? Contesting the Dualism of Legal Worker Identities. California Law Review 105: 65-123. 
Euler, Johannes. 2018. Conceptualizing the Commons: Moving Beyond the Goods-Based Definition by Introducing the Social Practices of Commoning as Vital Determinant. Ecological Economics 143: 10. [CrossRef]

Evans, David S. 2003. The Antitrust Economics of Multi-Sided Platform Markets'. Yale Journal on Regulation 20: 325. Evans, David S., and Richard Schmalensee. 2016. Matchmakers: The New Economics of Multisided Platforms. Boston: Harvard Business Review Press.

Ferreri, Mara, and Romola Sanyal. 2018. Platform economies and urban planning: Airbnb and regulated deregulation in London. Urban Studies 55: 3353-68. [CrossRef]

Frenken, Koen, and Juliet Schor. 2017. Putting the sharing economy into perspective. Environmental Innovation and Societal Transitions 23: 3-10. [CrossRef]

Geissinger, Andrea, Christofer Laurell, Christina Öberg, and Christian Sandström. 2019. How sustainable is the sharing economy? On the sustainability connotations of sharing economy platforms. Journal of Cleaner Production 206: 419-29. [CrossRef]

Ghosh, Parikshit, and Debraj Ray. 2016. Information and Enforcement in Informal Credit Markets. Economica 83: 59-90. [CrossRef]

Guyader, Hugo. 2018. No one rides for free! Three styles of collaborative consumption. Journal of Services Marketing 32: 692-714. [CrossRef]

Hardin, Garrett. 1968. The Tregedy of the Cornrnonds. Science 162: 1243-48.

Hendrickson, Cary Y., Venere S. Sanna, and Filippo Celata. 2017. The sharing economy as community marketplace? Trust, reciprocity and belonging in peer-to-peer accommodation platforms. Cambridge Journal of Regions, Economy and Society 10: 349-63.

Huws, Ursula. 1998. Labor in the Global Digital Economy: The Cybertariat Comes of Age. New York: NYU Press.

Kant, Immanuel, and Mary J. Gregor. 1996. The Metaphysics of Morals. Cambridge: Cambridge University Press.

Kenney, Martin, and John Zysman. 2016. The Rise of the Platform Economy. Issues in Science and Technology 32: 3.

Kochan, Donald J. 2017. I share, therefore it's mine. University of Richmond Law Review 51: 909. [CrossRef]

Lamberton, Cait P., and Randall L. Rose. 2012. When Is Ours Better Than Mine? A Framework for Understanding and Altering Participation in Commercial Sharing Systems. Journal of Marketing 76: 109-25. [CrossRef]

Langley, Paul, and Andrew Leyshon. 2017. Platform capitalism: The intermediation and capitalization of digital economic circulation. Finance and Society 3: 11-31. [CrossRef]

Locke, John. 1690. Second Treatise on Government. In Two Treatises of Government: In the Former, The False Principles, and Foundation of Sir Robert Filmer, and His Followers, Are Detected and Overthrown. The Latter Is an Essay Concerning The True Original, Extent, and End of Civil GovernmentSecond Treatise of Government. London and New York: NYU Press.

Lovelock, Christopher, and Evert Gummesson. 2004. Whither Services Marketing? In Search of a New Paradigm and Fresh Perspectives. Journal of Service Research 7: 20-41. [CrossRef]

Malgieri, G. 2016. Property and (Intellectual) Ownership of Consumers' Information: A New Taxonomy for Personal Data. Privacy in Germany 4: 133. [CrossRef]

Mankiw, N. Gregory. 2018. Principles of Economics (Eighth). Boston: Cengage Learning.

Martin, Chris J. 2016. The Sharing Economy: A Pathway to Sustainability or a Nightmarish Form of Neoliberal Capitalism? Ecological Economics 121: 149. [CrossRef]

Marx, Karl. 1887. Capital a Critique of Political Economy Volume I Book One: The Process of Production of Capital. Moscow: USSR.

Marx, Karl, and Frederich Engels. 1964. The German Ideology. Moscow: Progress.

Merrill, T.W. 1998. Property and the right to exclude. Nebraska Law Review 77: 730.

Moeller, Sabine, and Kristina Wittkowski. 2010. The burdens of ownership: Reasons for preferring renting. Managing Service Quality: An International Journal 20: 176-91. [CrossRef]

Morgan, Bronwen, and Declan Kuch. 2020. Diverse Legalities: Pluralism and Instrumentalism. In The Handbook of Diverse Economies. London: Edward Elgar Publishing.

Morozov, Evgeny. 2013. The 'Sharing Economy' Undermines Workers' Rights. The Financial Times. Available online: https://ft.com (accessed on 1 October 2020).

Mossoff, Adam. 2012. Saving Locke from Marx: The Labor Theory of Value in Intellectual Property Theory. Social Philosophy and Policy 29: 283-317. [CrossRef]

Nozick, Robert. 1974. Anarchy, State, and Utopia. New York: Basic Books. 
Ostrom, Elinor. 1990. Governing the Commons: The Evolution of Institutions for Collective Action. Cambridge: Cambridge University Press.

Ostrom, Elinor. 2003. How Types of Goods and Property Rights Jointly Affect Collective Action. Journal of Theoretical Politics 15: 239-70. [CrossRef]

Ravenelle, Alexandra J. 2017. Sharing economy workers: Selling, not sharing. Cambridge Journal of Regions Economy and Society 10: 281-95. [CrossRef]

Richardson, Lizzie. 2015. Performing the sharing economy. Geoforum 67: 121-29. [CrossRef]

Rifkin, Jeremy. 2001. The Age of Access: The New Culture of Hypercapitalism, Where All of Life Is a Paid-For Experience. The Journal of Education, Community and Values 2. Available online: http://bcis.pacificu.edu/ journal/2002/04/bookrev1.php (accessed on 30 October 2020).

Saccani, Nicola, Marco Perona, and Andrea Bacchetti. 2017. The total cost of ownership of durable consumer goods: A conceptual model and an empirical application. International Journal of Production Economics 183: 1-13. [CrossRef]

Schor, Juliet B. 2017. Does the sharing economy increase inequality within the eighty percent?: Findings from a qualitative study of platform providers. Cambridge Journal of Regions Economy and Society 10: 263-79. [CrossRef]

Schor, Juliet B., and William Attwood-Charles. 2017. The 'sharing' economy: Labor, inequality, and social connection on for-profit platforms. Sociology Compass 11: 8. [CrossRef]

Schor, Juliet B., Connor Fitzmaurice, Linsey B. Carfagna, William Attwood-Charles, and Emilie D. Poteat. 2016. Paradoxes of openness and distinction in the sharing economy. Poetics 54: 66-81. [CrossRef]

Sheehan, Duncan. 2017. The Principles of Personal Property law. Portland and Oxford: Hart Publishing.

Sorenson, Andre. 2009. Neighborhood Streets as Meaningful Spaces: Claiming Rights to Shared Spaces in Tokyo: Neighborhood Streets as Meaningful Spaces. City and Society 21: 207-29. [CrossRef]

Stabrowski, Filip. 2017. 'People as businesses': Airbnb and urban micro-entrepreneurialism in New York City. Cambridge Journal of Regions Economy and Society 10: 327-47. [CrossRef]

Stern, James Y. 2017. The Essential Structure of Property Law. Michigan Law Review 115: 1167-212.

Sundararajan, Arun. 2016. The Sharing Economy: The End of Employment and the Rise of Crowd-Based Capitalism. Cambridge: MIT Press.

Terranova, Tiziana. 2000. Free Labor. Social Text 18: 33-58. [CrossRef]

Terranova, Tiziana. 2004. Network Culture: Politics for the Information Age. London: Pluto Press.

Teubner, Tim, Florian Hawlitschek, and David Dann. 2017. Price Determinants of Airbnb: How Reputation Pays Off in the Sharing Economy. Journal of Self-Governance and Management Economics 5: 53-80.

Traum, Alexander B. 2016. Sharing risk in the sharing economy: Insurance regulation in the age of Uber. Cardozo Public Law, Policy and Ethics Journal 14: 511.

Wallenstein, Judith, and Urvesh Shelat. 2017. Hopping Aboard the Sharing Economy. BCG Henderson Institute. Available online: www.bcg.com (accessed on 1 October 2020).

Werbach, Kevin. 2017. The Song Remains the Same: What Cyberlaw Might Teach the Next Internet Economy. Florida Law Review 69: 887.

Publisher's Note: MDPI stays neutral with regard to jurisdictional claims in published maps and institutional affiliations.

(C) 2020 by the author. Licensee MDPI, Basel, Switzerland. This article is an open access article distributed under the terms and conditions of the Creative Commons Attribution (CC BY) license (http://creativecommons.org/licenses/by/4.0/). 